direct. We have now become accustomed to the use of solid carbon dioxide for the refrigeration on the tricycles in which ice-cream is transported in the big towns. It has, however, many other industrial uses, and as many as 60,000-70,000 tons are now produced per annum in the United States. A surprising fact is that its loss by evaporation is quite moderate, being about 1-2 per cent by weight in 24 hours, on blocks of the ordinary size. It is also interesting to note that the gas itself, which surrounds the solid block, is a poor thermal conductor. This atmosphere of carbon dioxide is very useful when the solid material-'dry ice'-is used for the preservation of meat and fruit, since it prolongs the life of the latter, and tends to inhibit the growth of moulds and bacteria in the former case.

A growing, but less-known, use of 'dry ice' is in the machine shop, where it can be used for shrinking one part on to another, so that after the inner one warms up and expands, the joint is of enormous strength.

Solid carbon dioxide, like liquid oxygen, has removed the necessity for transporting heavy empty cylinders when supplies of the gas are required at a distance. By purchasing a block of 'dry ice', a customer with a suitable pressure vessel can obtain a supply of carbon dioxide gas from a cylinder which need never leave his premises. He simply inserts the block, closes the vessel and allows the carbon dioxide to evaporate. The gas so obtained is much purer than that from which the 'dry ice' was originally made, since the process has many of the features of the chemist's purification process of recrystallization.

Taken together, the seven lectures illustrate in a forceful manner the strides which have been made in the science and art of low temperature production and utilization, and also the interdependence of pure and applied science. The authorities of the Science Museum are to be congratulated on the provision of the course, which must have added very considerably to the interest of the Very Low Temperatures Exhibition itself, valuable though it would have been without them. J. H. A.

\title{
Obituary
}

\section{Sir William Hamer}

$\mathrm{B}^{\mathrm{x}}$ $Y$ the death on July 7 of Sir William Heaton Hamer, at the age of seventy-four years, epidemiology has been deprived of one of its most zealous students.

William Hamer (he was knighted in 1923) was a scholar of Christ's College, Cambridge, and graduated twelfth wrangler in 1882. After graduating in medicine, he entered the Medical Department of the London County Council and rose to be Medical Officer in 1911 , retiring in 1925 .

Hamer's mathematical training showed itself in some of his earlier researches, particularly his elucidation of the periodicity of measles in London, which he attributed to rhythmic variation in the number of susceptibles in the population. His work on these lines was afterwards extended by the late H. E. Soper and, although it is now held that the phenomenon is not quite so simple as Hamer suggested, there is little doubt that changes in the proportion of susceptibles form an important element of the general problem.

Hamer was an acute critic of popular epidemiological theories, particularly those based upon bacteriological findings, and a sturdy champion of the doctrine of epidemic constitutions, to which he devoted years of study. The "English Hippocrates", Thomas Sydenham, propounded the general doctrine that all forms of acute diseases prevailing at the same time were linked together by common features in consequence of some general, possibly cosmic, influence which he was unable to define. Hamer attempted to bring this rather vague hypothesis into conformity with modern seientific results. It is generally agreed that, in pointing out the chronological relation of prevalences of obscure nervous diseases to pandemics of influenza, and in explaining the nature of such mysterious epidemies as the 'sweats' of the sixteenth century, Hamer made important contributions to knowledge. To most students, how. ever, his later writings were difficult to follow, and he seemed to exaggerate the importance of Syden. ham's views. At his best, he was a most stimulating writer, and he continued the scholarly tradition of Charles Creighton, linking modern science to the philosophical outlook of the ancient masters.

\section{Mr. W. Newbold}

The death, on June 24, of William Newbold, classical scholar, self-taught mathematician, statistician and biologist, at the age of fifty-eight years, just as he was within sight of retirement from his duties as an inspector of secondary schools under the Board of Education, and was wishing for leisure to extend his biological investigations, was a great shock to the large circle of friends to whom he had endeared him. self by his ever-ready help and wise and kindly counsel.

Though Newbold never lost his delight in classical and archæological studies, his latent first-rate mathe- 
matical ability was, in his early manhood, stimulated by his desire to study astronomy; this led to the mastering of relativity and its application to cosmic theories ; statistics next engaged his attention ; and his work in this direction was invaluable to his colleagues. His eager avidity for knowledge of all kinds later drew him towards biology : here his love of observation and experimentation found its best outlet, and his work ranged over a wide field of natural history. Drawn by his combined interest in statistics and biology, he bred stick insects, to investigate their rate of increase, over a long period, keeping them in muslin meat safes, until they overflowed his study, his bedroom and his laboratory (a disused windmill). He was particularly interested in small insect parasites, especially those of birds.

The most modest and retiring of men, it never occurred to Newbold to publish any of the curious and interesting observations he made, though they were shared from time to time with his more intimate friends. A man of unusually powerful intellect, of the widest interests and sympathies, there can be no doubt that, with release from routine duties, he would have made valuable contributions to science. He met his end, which he knew for some months to be near at hand, with the utmost calm and fortitude. It is not so much as a potential man of science, but as one of far-seeing and disinterested judgment, whose wisdom in affairs was always freely at the disposal of his friends, that he will be missed.

\section{Dr. H. J. Hansen}

Dr. Hans Jacob Hansen, who died on June 26 at Gjentofte, near Copenhagen, in his eighty-first year, was one of the most distinguished of the long line of descriptive zoologists who have placed the Zoological Museum of Copenhagen in the very front rank of the museums of the world.

Hansen was born at Bellinge in the district of Odense on August 10, 1855, and studied at the University of Copenhagen, where he took the degree of Dr. phil, in 1883 with a thesis on the mouth-parts of Diptera ("Fabrica oris Dipterorum"). While still a student he worked at the Museum under J. M. C. Schiødte and in 1885 he was appointed an assistant in the entomological department, a position which he held until 1910, when in consequence of some changes in the staff he felt compelled to resign. At this time, when the continuance of his scientific work seemed to be in danger, a letter was addressed to him by a large number of zoologists in Great Britain expressing their high appreciation of his researches and their hope that he would be placed in a position to continue them. This letter was published in Nature on March 10, 1910. Together with the efforts of his scientific friends in Denmark, this led to his being allowed to retire on full pay (although this was small enough, even by Danish standards) "for free scientific activity". He continued to work unremittingly, and letters received from him in the last year of his life were full of work in hand and plans for the future.
Except for an early contribution to the account of Danish fishes in Schiødte's "Zoologica Danica", all Hansen's published works deal with Arthropoda. Within the limits of that vast phylum, however, their range is wider than that attempted by any other zoologist of our time. Insects, Myriopoda, Crustacea, and Arachnida formed the subjects of numerous memoirs and monographs that for fullness and accuracy of detail and for exquisite illustration have never been surpassed.

Hansen's attention was especially attracted by those groups that by reason of their annectent affinities are of crucial importance to the morphologist. Thus he monographed the Arachnid Palpigradi and Podogona (until the other day among the rarest of animals) and the Myriopod Pauropoda and Symphyla; but it was on the Crustacea that the greater part of his work was done. When taking part in the first cruise of the Ingolf expedition to the seas of Iceland and Greenland in 1895, he devised a method of sifting the bottom deposits that revealed an astonishing variety of minute Crustacea, and he later published memoirs on the Isopoda and Tanaidacea in which large numbers of new genera and species were established, but the material of many groups still remains undescribed. Even now, little attention has been given to this micro-fauna of the sea-bottom, although it may conceivably play an important part in marine ecology.

Perhaps the most important of Hansen's contributions to morphology was a little paper on the limbs and mouth-parts of Crustacea and insects published in the Zoologischer Anzeiger in 1893. This was intended as preliminary to an extensive treatise on the subject which unfortunately never appeared, for when at length he published his "Studies on Arthropoda" in 1921-30, he confined himself to elaborating the details without developing further the broader views sketched in the early paper.

Apart from zoology, Hansen's interests lay mainly in politics and in military history. On these subjects he wrote much in newspapers and magazines, and he published a number of pamphlets mostly with the object of warning his countrymen against the increasing influence of German culture and German politics. He urged Danish science students to look to England rather than to Germany as their 'spiritual home', and was a caustic critic of the "Germanisering af Dansk Videnskab". Nearly all his scientific papers were published in English. In 1902 he was elected a foreign member of the Linnean Society of London.

$$
\text { W. T. Calman. }
$$

\section{WE regret to announce the following deaths:}

Sir Arnold Theiler, K.C.M.G., well known for his work in veterinary research and education in South Africa, on July 24, aged sixty-nine years.

Sir Henry Wellcome, F.R.S., governing director of the Wellcome Foundation, founder of the Wellcome Research Institution, and founder and director of the Wellcome Historical Medical Museum, on July 25, aged eighty-two years. 